\title{
Proposal of Innovative Flooring Options for Marine Containers
}

\author{
Martina Hlatká \\ Institute of Technology and Business in \\ České Budějovice \\ Faculty of Technology, Department of \\ Transport and Logistics \\ Czech Republic \\ e-mail: hlatka@mail.vstecb.cz
}

\author{
Ondrej Stopka \\ Institute of Technology and Business in \\ České Budějovice \\ Faculty of Technology, Department of \\ Transport and Logistics \\ Czech Republic \\ e-mail: stopka@mail.vstecb.cz
}

\author{
Mária Stopková \\ Institute of Technology and Business \\ in České Budějovice \\ Faculty of Technology, Department of \\ Transport and Logistics \\ Czech Republic \\ e-mail: stopkova@mail.vstecb.cz
}

DOI 10.17818/NM/2018/4SI.2

UDK 621.798:656.61

Original scientific paper

Paper accepted: 28. 8. 2018.

\section{Summary}

The paper outlines the innovative and progressive flooring options to build and equip marine containers. Several measurements, tests and simulations within this research study have been performed to find out whether it is possible to upgrade the marine container for general purposes with the polypropylene board with aluminum reinforcement. Research has confirmed that the aluminum board has a number of advantages. The main advantages include more than two times longer service lifespan compared to the conventional floors, absolute resistance to biological and chemical agents and simple floor repairs. Due to its durability, the aluminum board has a significant economic benefit for the user as well.

\section{KEY WORDS}

marine container

transport

polypropylene board

aluminum reinforcement

board mechanical deformations

toxicity test

intermodal transport terminal

\section{INTRODUCTION}

The development of international trade comprises increased transport requirements. For this reason, the great emphasis is placed on ensuring that transport is as least costly as possible, including in relation to the environment. Due to the high share of export and import, road, maritime, railway and intermodal transport terminals have persistently been developed. All these modes of transport use containers for cargo transportation. The container system is one of the most widespread, the most significant and the most advanced system applicable not only in the intermodal transport. Marine container is a standardized intermodal transport unit adjusted for carrying, stowing and stacking of cargo. Basically, it is a dimensional (bulky) solid, totally or partially closed, unit designed to move (carry) materials. At present, the most used container type is of a steel frame, reinforced by steel sheets, and wood flooring. Container service lifespan varies among 10-15 years. During this time period, the wooden floor must be replaced by the new one at least three times. Containers have become an important element in the globalization of international trade. As the importance of this business grows, it is also necessary to focus on the innovation of the most used means of transport. This paper will focus on the possibility of replacing the wood flooring by another material [1-7].

\section{DATA, METHODS AND EXAMINATION}

For this study, a polypropylene board with aluminum reinforcement (hereinafter referred to as the "Al board") of the Beta company (hereinafter referred to as " $\mathrm{B}$ ") was selected.
In the first place, the board passes through a simulation analysis. Testing the board is carried out by the software simulation and diagnostic tests. In addition, microscopic techniques to determine the internal and surface structure of boards are utilized. The board of the B company and board of the competing company Alfa (A) are compared within the microscopic comparison. Diagnostic tests require, in particular, flammability tests, odor tests and tests for the presence of dangerous substances required for contact with foodstuffs. As a final test, a board floor strength test is performed [8-10].

\subsection{Simulation of material in deflection}

To perform the simulation process, a $1 \times 1 \mathrm{~m}$ board and $20 \mathrm{~mm}$ thick with a flexural modulus (indicated by a yellow color) is used. During this simulation, the board was supported on its periphery by a $20 \mathrm{~mm}$ wide surface. The Al board was loaded with a force at its center of $2.5 \mathrm{kN}$ plus the actual board weight. This simulation is depicted in Figure 1.

From the simulation process, it is obvious that the largest deflection is reached directly at the point where the board is loaded, with a value of $2.85 \mathrm{~mm}$. Prior to putting it into practice, it is necessary to examine whether this deflection would affect the board functionality during the repeated loading [9-12]:

\subsection{Simulation of material in stress}

As for another simulation process, a board of the same dimensions with a flexural modulus of $5,200 \mathrm{MPa}$ was simulated using the Cad/Cam software. During the simulation 


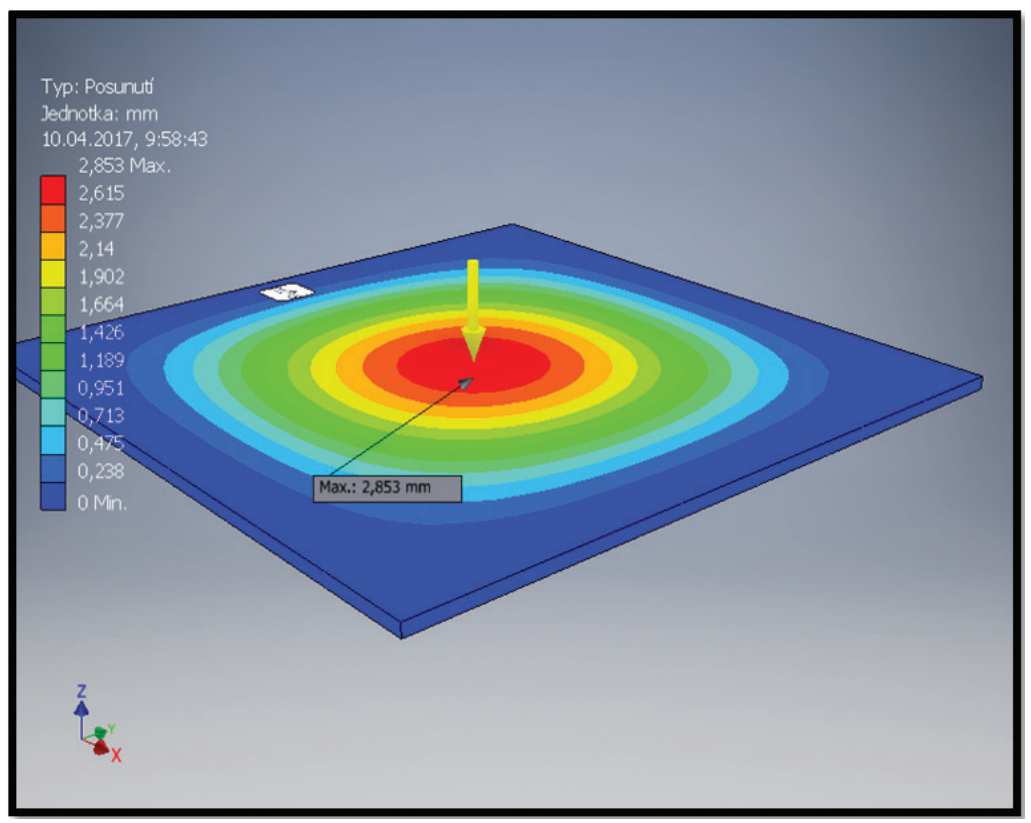

Source: authors

Figure 1 Board simulation in deflection

process, the board was supported on its periphery by a $20 \mathrm{~mm}$ wide surface. The board was loaded with a force at its center of $2.5 \mathrm{kN}$ plus the actual board weight. The highest stress focal points are marked by yellow and red color in Figure 2 .

The Von Mises stress simulation depicts that the highest stress is concentrated at the board edges at their center on the reverse side. In practice, this means that these Al boards must be carefully anchored, for example, by rivets at these places where they might be cut or damage the board [9-13]:

\subsection{Board thickness}

If the wooden floor is to be replaced by another board, it is necessary to find the appropriate material. This material must meet the requirements for mechanical deformation of dynamic impact or long-term cyclic wear. On the other hand, the emphasis must be placed on the board weight and the cost of the used material. Microscopic assessment was performed using boards of the competing A company and the B company boards. All samples were measured by optical microscope and subsequently evaluated. The results confirm that the $A$ company exclusively uses $\mathrm{Al}$ foil with a thickness of $0.4 \mathrm{~mm}$ for its products. The thickness of the cover polypropylene (PP) board is diverse, for product thicknesses of 12.5 and $20 \mathrm{~mm}$, it is of $1.5 \mathrm{~mm}$ and for thicknesses of products of 17 and $27 \mathrm{~mm}$, it is of $2 \mathrm{~mm}$, as shown in Figure 3 [14].

In Table 1, materials of individual thicknesses related to

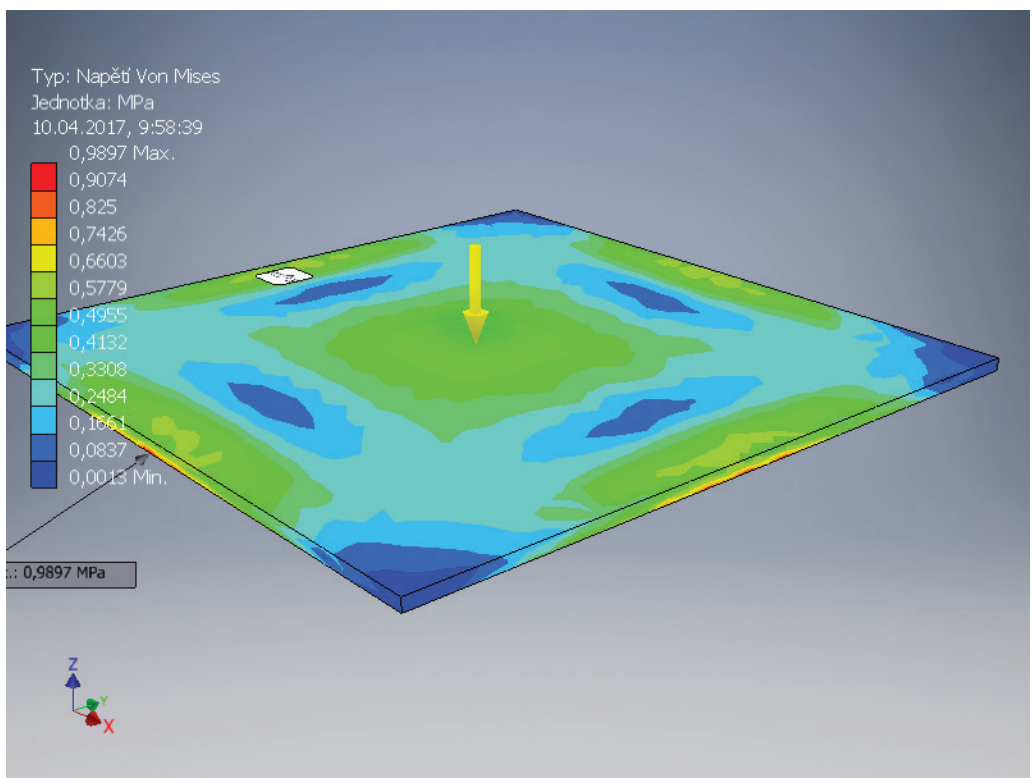

Source: authors

Figure 2 Board simulation in stress 


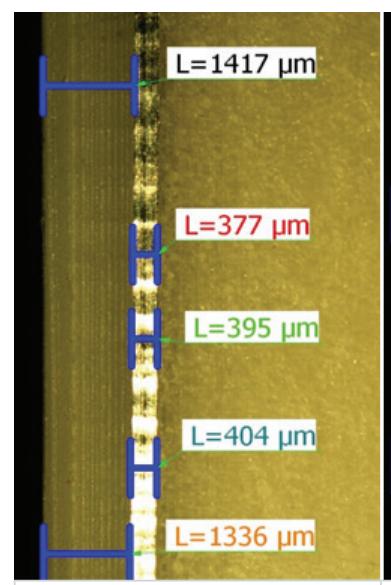

Board $12.5 \mathrm{~mm}$

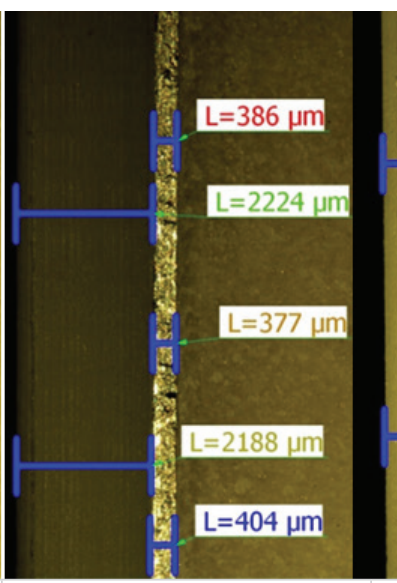

Board $17 \mathrm{~mm}$

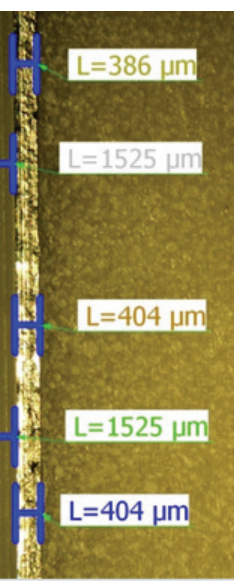

Board $20 \mathrm{~mm}$

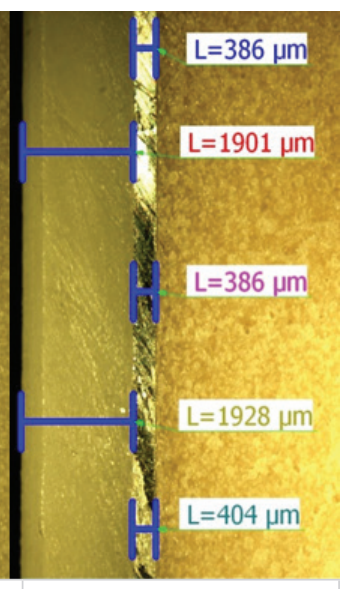

Board $27 \mathrm{~mm}$

Source: authors

Figure 3 Microscopic measurement of Al boards of the A company

Table 1 Comparison of individual boards parameters

\begin{tabular}{|c|c|c|c|c|c|c|c|c|c|}
\hline \multirow[b]{2}{*}{ nominal thickness } & \multirow[b]{2}{*}{$\mathrm{mm}$} & \multicolumn{4}{|c|}{ A company } & \multicolumn{4}{|c|}{ B company } \\
\hline & & 12.5 & 17 & 20 & 27 & 10 & 12.5 & 15 & 17 \\
\hline actual thickness & $\mathrm{mm}$ & 12.32 & 16.58 & 20.13 & 26.57 & 9.8 & 12.3 & 14.87 & 16.95 \\
\hline Al foil thickness & $\mathrm{mm}$ & 0.4 & 0.4 & 0.4 & 0.4 & 0.28 & 0.28 & 0.28 & 0.4 \\
\hline PP foil thickness & $\mathrm{mm}$ & 1.5 & $2.2-2.4$ & 1.5 & 2.0 & 1.0 & 1.0 & 1.0 & 1.2 \\
\hline density & $\mathrm{kg} / \mathrm{m} 2$ & 0.81 & 0.79 & 0.71 & 0.72 & 0.79 & 0.74 & 0.69 & 0.72 \\
\hline basis weight & $\mathrm{MPa}$ & 10.03 & 13.04 & 14.32 & 19.15 & 7.61 & 9.14 & 10.31 & 12.17 \\
\hline flexural strength & $\mathrm{MPa}$ & 52 & 44 & 40 & 37 & 59 & 52 & 45 & 43 \\
\hline flexural modulus & $\mathrm{MPa}$ & 6,100 & 4454 & 5,227 & 4,447 & 5,793 & 5,532 & 4,943 & 6,134 \\
\hline tensile strength & $\mathrm{MPa}$ & 26 & 23 & 20 & & 31 & 26 & 24 & 21 \\
\hline ductility & $\%$ & 4.08 & 5.01 & 5.54 & & 5.7 & 6.37 & 9.7 & 11.6 \\
\hline
\end{tabular}

Source: authors

the dimensions, layers, weights and mechanical properties are compared. The B company have included among the portfolio of products the thicknesses of $10,12.5,15$ and 17 $\mathrm{mm}$. Results of microscopic measurements of the B company are summarized in Table 1 as well. For thicknesses over 15 $\mathrm{mm}, \mathrm{Al}$ foil of $0.4 \mathrm{~mm}$ thick and cover PP foil of $1.2 \mathrm{~mm}$ are used. In order to compare Al boards and material of the $A$ and $B$ companies with respect to the physical and mechanical properties of boards, it is necessary to compare the selected material of $12.5 \mathrm{~mm}$ thickness (strength) manufactured by both companies.

The table shows that properties such as tensile and flexural strength and their modules do not have a great effect on the diverse thicknesses of the Al and PP foils and these properties are similar for both companies. These diverse layer thicknesses have a significant effect on the basis weight, where differences can be noticed, especially for different Al foil thicknesses, where the material basis weight of the A company increases. As for density, the difference is not so notable thanks to lightening the center layer for both manufacturers. The result of the comparison is that the Al board of the $B$ company shows better outcomes regarding the basis weight and density with similar physical and mechanical properties as the competing products.

\subsection{Toxicity test}

This test covers obtaining the rate of the released heat increase from the burning material. This test is required for the boards' utilization in the NATO military field. Furthermore, toxicity test includes a test to obtain the amount of smoke released during combustion and the amount of toxic substances during combustion. Depending on how AL boards are used, three samples are tested, namely two variants of floor boards and material for walls and partitions construction.

Toxic yields of gaseous fumes of thermal decomposition/ combustion are expressed by values CIT in the 4th and the 8th minute, $\mathrm{FED}_{30 \mathrm{~min}}$ and $\mathrm{LC}_{58 \mathrm{~T} о \mathrm{~T}}$. The results are summarized in the following Table 2, whereby test procedure met the standard "ISO 5659-2: 2017 Plastics - Smoke generation - Part 2: Determination of optical density by a single-chamber test" [9], [11], [15-18].

The values marked with asterisks represent detection limits of analysis for individual components. Samples are burned at the prescribed heat flow whereby the optical density of the smoke over time is determined. The maximum value $D_{\text {SMAX }}$ is the evaluation criterion. Tested samples have the values of $D_{\text {SMAX }} 56$. The test had positive results for all the tested samples and the Al board complies with the fire regulations required for material utilization in maritime transport. 
Table 2 Resulting values of the toxicity test

\begin{tabular}{|c|c|c|c|c|c|c|c|c|c|}
\hline Sample & Time & $\begin{array}{c}\mathrm{CO} \\
{\left[\mathrm{mg} / \mathrm{m}^{3}\right]}\end{array}$ & $\begin{array}{c}\mathrm{CO}^{2} \\
{\left[\mathrm{mg} / \mathrm{m}^{3}\right]}\end{array}$ & $\begin{array}{c}\mathrm{HCl} \\
{\left[\mathrm{mg} / \mathrm{m}^{3}\right]}\end{array}$ & $\begin{array}{c}\mathrm{HBr} \\
{\left[\mathrm{mg} / \mathrm{m}^{3}\right]}\end{array}$ & $\begin{array}{c}\mathrm{HF} \\
{\left[\mathrm{mg} / \mathrm{m}^{3}\right]}\end{array}$ & $\begin{array}{c}\mathrm{HCN} \\
{\left[\mathrm{mg} / \mathrm{m}^{3}\right]}\end{array}$ & $\begin{array}{c}\mathrm{SO}^{2} \\
{\left[\mathrm{mg} / \mathrm{m}^{3}\right]}\end{array}$ & $\begin{array}{c}\mathrm{NO}_{[\mathrm{x}} \\
{\left[\mathrm{mg} / \mathrm{m}^{3}\right]}\end{array}$ \\
\hline \multirow{2}{*}{$1 a$} & 4.min & 96 & 34,556 & $<98^{*}$ & $<90^{*}$ & $<17^{*}$ & $<30^{*}$ & $<56^{*}$ & $<31^{*}$ \\
\hline & 8.min & 139 & 52,194 & $<98^{*}$ & $<90^{*}$ & $<17^{*}$ & $<30^{*}$ & $<56^{*}$ & $<31^{*}$ \\
\hline \multirow{2}{*}{$1 b$} & 4. $\min$ & 133 & 33,711 & $<98^{*}$ & $<90^{*}$ & $<17^{*}$ & $<30^{*}$ & $<56^{*}$ & $<31^{*}$ \\
\hline & 8.min & 163 & 54,376 & $<98^{*}$ & $<90^{*}$ & $<17^{*}$ & $<30^{*}$ & $<56^{*}$ & $<31^{*}$ \\
\hline \multirow{2}{*}{$1 c$} & 4.min & 59 & 31,688 & $<98^{*}$ & $<90^{*}$ & $<17^{*}$ & $<30^{*}$ & $<56^{*}$ & $<31^{*}$ \\
\hline & 8.min & 96 & 50,135 & $<98^{*}$ & $<90^{*}$ & $<17^{*}$ & $<30^{*}$ & $<56^{*}$ & $<31^{*}$ \\
\hline \multirow{2}{*}{$\bar{x}_{i}$} & 4.min & 96 & 33,318 & $<98^{*}$ & $<90^{*}$ & $<17^{*}$ & $<30^{*}$ & $<56^{*}$ & $<31^{*}$ \\
\hline & 8.min & 133 & 52,235 & $<98^{*}$ & $<90^{*}$ & $<17^{*}$ & $<30^{*}$ & $<56^{*}$ & $<31^{*}$ \\
\hline \multirow{2}{*}{$\mathrm{S}_{\mathrm{xi}}$} & 4.min & 44 & 1,694 & - & - & - & - & - & - \\
\hline & 8.min & 39 & 2,506 & - & - & - & - & - & - \\
\hline $\mathrm{CIT}_{4 \min } \pm \mathrm{U}$ & \multicolumn{9}{|c|}{$0.40 \pm 0.12$} \\
\hline $\mathrm{ClT}_{8 \min } \pm \mathrm{U}$ & \multicolumn{9}{|c|}{$0.43 \pm 0.13$} \\
\hline $\mathrm{FED}_{30 \min } \pm \mathrm{U}$ & \multicolumn{9}{|c|}{$0.40 \pm 0.12$} \\
\hline $\mathrm{LC}_{58 \mathrm{TOT}} \pm \mathrm{U}$ & \multicolumn{9}{|c|}{$38.57 \pm 11.57$} \\
\hline
\end{tabular}

Source: authors, based on [18]

Explanatory notes:

- $\quad \bar{x}_{i}$ - arithmetic mean of the component $i$ concentration calculated from 3 result values measured under repeatability conditions rounded to the nearest integer;

- $\quad S_{x i}$ - standard deviation xi calculated from the span;

- CIT - conventional toxicity index (dimensionless variable);

- FED - total fractional effective dose (dimensionless variable);

- $\quad$ LC - lethal concentration $\left[\mathrm{g} / \mathrm{m}^{3}\right]$;

- $\quad U$ - Extended uncertainty $(k=2)$ corresponding to $95 \%$ confidence interval.

\subsection{Floor strength test}

Test to determine the floor strength is the last examination kind within this research study. The floor strength is precisely determined by the standard "Series 1 freight containers Specification and testing - Part 1: General cargo containers for general purposes". This Standard is a Czech version of the International Standard ISOĐ 1496-16: 2013 with the identical title. The floor strength test is carried out in order to prove the ability of the container floor to withstand the concentrated dynamic loading caused by industrial trucks or similar equipment used for material operations [7], [19], [20].

The examination was carried out using a test vehicle equipped with tires with an axle load of 7,260 kg, i.e. 3,630 kg per wheel. The configuration was such that all the points of contact among each wheel and the flat continuous surface were located within a rectangle with dimensions of $185 \mathrm{~mm}$ (in a direction parallel to the wheel's axis) $\times 100 \mathrm{~mm}$. Each wheel had a physical contact on the area in this rectangle that was not bigger than $142 \mathrm{~cm}$. The nominal wheel width was $180 \mathrm{~mm}$ and the wheels centers had to have the value of $760 \mathrm{~mm}$. The tested vehicle had to maneuver across the whole container floor surface, especially in the area of joints and the entrance edges. The examination was carried out on a container placed on four planar supports, under its four lower corner elements so that the bottom structure had the possibility of free deflection. The width of the test loading was limited to the wheels total width [1], [5], [20-22].

After performing the test, the container showed no permanent deformation or abnormality rendering it unsuitable for use. In order to approve the examination, it must be carried out by the accredited laboratory.

\section{RESULTS}

After physical-mechanical examination of boards of diverse thicknesses and comparison with the competition, the optimal strength of the Al board material for research study regarding the container innovation options has been found. The following Table 3 shows two samples of the Al board of the B company intended to be researched, the ordinary cementbonded board and the competing board samples of the $A$ company. All these materials are intended for the containers flooring.

Table 3 Appropriate Al board selection for container flooring

\begin{tabular}{|c|c|c|c|c|c|}
\hline & $\begin{array}{c}\text { A } \\
\text { company } \\
\text { AL board } \\
\text { of 20mm } \\
\text { thick }\end{array}$ & $\begin{array}{c}\text { A } \\
\text { company } \\
\text { AL board } \\
\text { of 21mm } \\
\text { thick }\end{array}$ & $\begin{array}{c}\text { Cement- } \\
\text { bonded } \\
\text { board of } \\
\text { 22mm } \\
\text { thick }\end{array}$ & $\begin{array}{c}\text { B } \\
\text { company } \\
\text { AL board } \\
\text { of 20mm } \\
\text { thick }\end{array}$ & $\begin{array}{c}\text { company } \\
\text { AL board } \\
\text { of 28 } \\
\text { mm thick }\end{array}$ \\
\hline $\begin{array}{c}\text { Von Mises } \\
\text { stress (MPa) }\end{array}$ & 1.37 & 1.27 & 1.20 & 1.40 & 0.99 \\
\hline $\begin{array}{c}\text { Deformation } \\
\text { (mm) }\end{array}$ & 1.78 & 1.57 & 1.57 & 1.77 & 2.86 \\
\hline
\end{tabular}

Source: authors

After evaluating all the tests and comparing the material with the competitor, the composite Al board of the B company was approved for the research study of the container flooring innovation. It is possible to select a board with a thickness of 


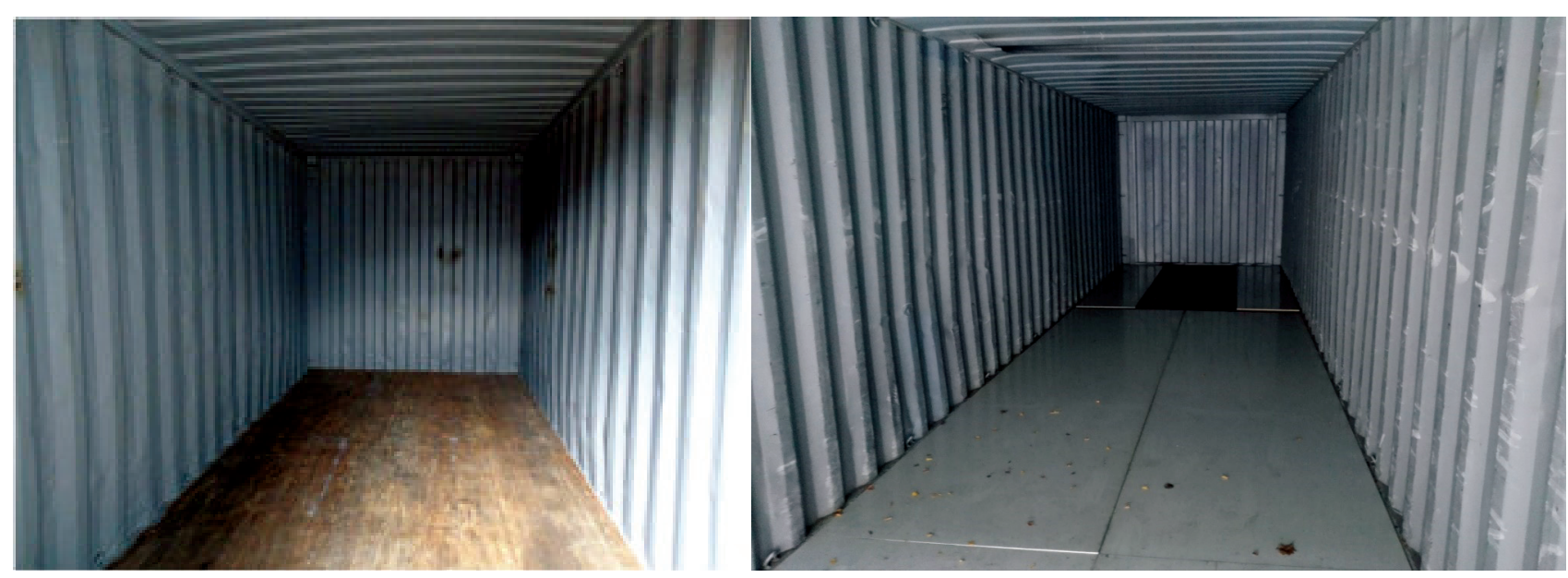

Source: authors

Figure 4 Container before and after the flooring innovation option application

$20 \mathrm{~mm}$ or $28 \mathrm{~mm}$. A low weight board is sufficient in terms of mechanical effort. The material complies with the fire and hygiene regulations, withstands any weather conditions, resists odor, mold and various biological agents. A great advantage of Al boards consists in their durability (long service lifespan) and simple reparability. In terms of its characteristics, material is ideally suited to manufacture special technological containers. Design of the container flooring before and after the innovation is illustrated in Figure 4 [23], [24].

\section{CONCLUSION}

The aim of this research study is to find out whether the current general purpose marine container flooring innovation is possible. Compared to the conventional container flooring solutions made of cement-bonded material, the Al board has a number of advantages. The main advantages include more than two times longer service lifespan, absolute resistance to biological and chemical agents and simple flooring reparability. Thanks to its durability, the aluminum board has a significant economic benefit for the user as well. Due to its properties, it is the ideal solution for utilization in the segment of special technological containers.

Al board is suitable for ISO container flooring, especially for special container manufacturers due to its durability, resistance to physical-biological agents and fire certificate. Necessary examinations have been carried out to ensure that the material has the proper physical-mechanical properties and that it meets the safety regulations required for the maritime transport. Since the price of the tested material is not high, these innovations also comply with the economic demands.

\section{REFERENCES}

[1] Levinson, M. How the shipping container made the world smaller and the world economy bigger. Published by Princeton University Press, Oxfordshire, UK, 2016. ISBN 978-0-691-17081-7.

[2] Lukoszova, X. Combined transport technologies in Europe. Logistika, Prague: Economia, a.s., 2015, Vol. 21, No. 3, pp. 32-35. ISSN 1211-0957.
[3] Machkova, H. Mezinárodní marketing: nové trendy a reflexe změn ve světě (International Marketing: New Trends and Reflections of Changes in the World; in Czech). Prague, Grada Publishing, Czech Republic, 2009. ISBN 978-80-247-2986-2.

4] Machkova, H., Černohlávková, E., Sato, A., et al. Mezinárodní obchodn operace (International Business Operations; in Czech). Prague, Grada Publishing, Czech Republic, 2014. ISBN 978-80-247-8022-1.

[5] Novak, J., Cempirek, V. Kombinovaná přeprava (Combined transport; in Czech). Pardubice, Jan Perner institute, Czech Republic, 2015. ISBN 97880-7395-948-7.

[6] Soltesz, $S$, et al. Container-based operating system virtualization: a scalable, high-performance alternative to hypervisors. In: ACM SIGOPS Operating Systems Review, 2007, pp. 275-287. https://doi. org/10.1145/1272998.1273025

[7] Stahlbock, R., VOß, S. Operations research at container terminals: a literature update. OR spectrum, 2008, Vol. 30, No. 1, pp. 1-52. https://doi. org/10.1007/s00291-007-0100-9

[8] Duksatko, A., et al. Skladové objekty a jejich provoz z pohledu bezpečnostních, hygienických a požárních předpisů (Warehouses and their operation in terms of safety, hygiene and fire regulations; in Czech). Olomouc, Anag, Czech Republic, 2012. ISBN 978-80-7263-756-0.

[9] Dvorak, O., Charvatova, V., Ruzicka, M. Nebezpečí toxicity zplodin hoření materiálů (Risk of combustion toxicity of materials; in Czech). Ed. 1. Prague: Tupo, 2007. ISBN 978-80-86640-92-1.

[10] Hermanns, H., Herzog, U., Mertsiotakis, V. Stochastic process algebras as a tool for performance and dependability modelling. In: Computer Performance and Dependability Symposium. Proceedings, IEEE, 1995. pp. 102-111.

[11] Lehmann, A., Lehmann, F. Messung, Modellierung und Bewertung von Rechensystemen, Springer Verlag, 2013. ISBN 978-3-540-54550-7.

[12] Stanova, E., Fedorko, G., Kmet, S., et al. Finite element analysis of spiral strands with different shapes subjected to axial loads. Advances in Engineering Software, 2015, Vol. 83, pp. 45-58. https://doi.org/10.1016/j. advengsoft.2015.01.004

[13] Fedorko, G., Stanova, E., Molnar, V., et al. Computer modelling and finite element analysis of spiral triangular strands. Advances in Engineering Software, 2014, Vol. 73, pp. 11-21. https://doi.org/10.1016/j. advengsoft.2014.02.004

[14] Schenk, P. Operationalisierung. In: Die soziale Einbettung moralischer Kaufentscheidungen. Springer VS, Wiesbaden, Germany, 2018, pp. $193-$ 209. https://doi.org/10.1007/978-3-658-18575-6_13

[15] Balog, K., Zapletalová-Bartlová, I. Základy toxikologie (Fundamentals of Toxicology; in (zech). Ostrava, Association of Fire and Safety Engineering in Ostrava, Czech Republic, 1998. ISBN 80-86111-29-6.

[16] Broumovská, I. Speciální chemie pro požární ochranu (Special chemistry for fire protection; in (zech). Prague, Seidl publisher, 1992. ISBN 80901368-0.

[17] Kmet, S., Stanova, E., Fedorko, G., et al. Experimental investigation and finite element analysis of a four-layered spiral strand bent over a curved support. Engineering Structures, 2013, Vol. 57, pp. 475-483. https://doi. org/10.1016/j.engstruct.2013.09.019 
[18] ISO 5659-2: 2017 Plastics - Smoke generation - Part 2: Determination of optical density by a single-chamber test. [online]. Available via: https:// www.iso.org/standard/65243.html.

[19] ČSN ISO 1496-1 (26 9343) Series 1 freight containers - Specification and testing - Part 1: General cargo containers for general purposes [online]. Available via: https://shop.normy.biz/detail/501861.

[20] Wei, J., Zeng, D., Guan, M.J. Research on the Bending Properties of the Bamboo-wood Container Flooring. Advances in Material Science, Mechanical Engineering and Manufacturing, Book Series: Advanced Materials Research, 2013, Vol. 744, pp. 366-369. In: 3rd International Conference on Machinery, Materials Science and Engineering Applications (MMSE 2013), Wuhan, China, Jun 20-21, 2013. https://doi.org/10.4028/ www.scientific.net/AMR.744.366

[21] Jagelčák, J., Kubasáková, I. Load distribution in general purpose maritime container and the analysis of load distribution on extendable semitrailer container chassis carrying different types of containers. Naše More, 2014, Vol. 61, Issue 5-6, pp. 106-116. ISSN 0469-6255.
[22] Jurkovič, M., Kalina, T., Turčan, R., Gardlo, B. Proposal of an enhanced safety system on board of the inland vessel. MATEC Web of Conferences, 2017, Vol. 134, Article number 00022, In: LOGI 2017 - 18th International Scientific Conference, Ceske Budejovice, Czech Republic, 2017. https:// doi.org/10.1051/matecconf/201713400022

[23] Caban, J., Brumercikova, E., Bukova, B., Brumercik, F., Vrábel, J., Šarkan, B. Ignaciuk, P. Conception of the Maritime Transport Safety in the Baltic Sea in 2009 to 2015. Logi - Scientific Journal on Transport and Logistics, 2017, Vol. 8, Issue 2, pp. 12-23. https://doi.org/10.1515/logi-2017-0012

[24] Lee, T. H. Maximum isoinertial lifting capabilities for different lifting ranges and container dimensions. Applied Ergonomics, Vol. 36, Issue 3, pp. 373-377. https://doi.org/10.1016/j.apergo.2004.07.007 